Documentation et bibliothèques

DOCUMENTATION BIBLIOTHËQUES

\title{
Réseau documentaire québécois
} A library and information network for Quebec

\section{Marcel Fontaine}

Volume 28, numéro 2, avril-juin 1982

Les réseaux documentaires au Québec

URI : https://id.erudit.org/iderudit/1053747ar

DOI : https://doi.org/10.7202/1053747ar

Aller au sommaire du numéro

\section{Éditeur(s)}

Association pour l'avancement des sciences et des techniques de la documentation (ASTED)

\section{ISSN}

0315-2340 (imprimé)

2291-8949 (numérique)

Découvrir la revue

\section{Citer cet article}

Fontaine, M. (1982). Réseau documentaire québécois / A library and information network for Quebec. Documentation et bibliothèques, 28(2), 85-95. https://doi.org/10.7202/1053747ar

Tous droits réservés (C) Association pour l'avancement des sciences et des techniques de la documentation (ASTED), 1982
Ce document est protégé par la loi sur le droit d'auteur. L'utilisation des services d'Érudit (y compris la reproduction) est assujettie à sa politique d'utilisation que vous pouvez consulter en ligne.

https://apropos.erudit.org/fr/usagers/politique-dutilisation/ 


\title{
Réseau documentaire québécois
}

\author{
Marcel Fontaine* \\ Bibliothèque nationale du Québec \\ Montréal
}

La lecture des articles ici réunis nous fournit des renseignements nombreux et à jour sur plusieurs facettes du "réseau documentaire québécois", son évolution, ses éléments principaux, ses objectifs, l'état de son développement et ses visions de l'avenir. Ces articles auront permis de recueillir des réponses adéquates à quelques questions, mais serviront surtout, nous l'espérons, à nous interroger sur bien d'autres points.

\section{Quelques lieux communs sur les réseaux}

II en est des réseaux comme des systèmes et des sociétés. Ils peuvent être petits ou grands, simples ou complexes; ils peuvent, pourvu bien sûr qu'ils existent, être actifs ou latents. Prenons, à titre d'exemple, le téléphone: c'est un point de comparaison qui fera bien l'affaire, car le téléphone est un réseau qui comporte une multitude de systèmes; il est de plus un moyen de communication. Or, la communication, personne ne le contestera, demeure le dénominateur commun des sociétés, des systèmes et des réseaux, lesquels n'ont d'ailleurs, tous et chacun, jamais plus de qualité que la qualité de leur communication.

Cette façon allégorique de procéder aura l'avantage de nous éviter d'établir des terminologies et des définitions. Celles-ci, pour être bien comprises, ont toujours besoins d'être accompagnées de longues explications et méritent plus qu'un traitement sommaire et marginal. Puisque nous sommes dans le domaine de la réflexion libre, il n'y a pas nécessité d'être exhaustif: comparaisons et explications tiendront lieu de définitions; le flou des termes non définis ouvrira la porte à des interprétations diverses et provoquera, nous l'espérons, des réflexions plus systématiques et plus savantes.

Quand un certain nombre d'éléments s'agencent entre eux d'une certaine façon, ils se donnent la possibilité d'interagir (entendez de communiquer entre eux): ils forment un système. Lorsque certaines autres conditions sont réunies, cette possibilité d'interagir devient réalité, interaction: il y a passage de l'état latent à la phase active. Et lorsque ce système est utilisé de façon consciente par l'homme, il devient système de communication, outil à son service.

Le téléphone, par exemple, limité à deux postes entrée/sortie serait un bien petit système: même reproduit à des millions d'exemplaires, il ne donnerait que des millions de petits systèmes. C'est donc en se complexifiant aux plans des choix et de la qualité de ses composantes qu'un système se perfectionne; c'est aussi en augmentant le nombre de ses postes entrée/sortie, c'est-à-dire en multipliant ses possibilités d'aiguillage, qu'il s'agrandit et qu'on commence à parler de réseau. De même, c'est seulement lorsqu'il est utilisé qu'il devient actif et que la communication se réalise; lorsqu'il est toujours prêt à entrer en action, il devient efficace; finalement, et de façon assez curieuse, dans la mesure où, tout en étant prêt à agir, il peut demeurer inactif, dans la même mesure il cesse d'être le maìtre pour devenir serviteur.

\section{Réseau documentaire québécois}

Ces éléments de comparaison une fois posés, essayons de voir un peu plus clair: qu'en est-il du réseau documentaire québécois? Et d'abord, existe-t-il? Nous

* L'auteur est conservateur adjoint. 
n'hésiterons pas à répondre que le réseau documentaire québécois n'existe pas encore. II existe bien quelque chose, beaucoup de choses même. Les composantes éventuelles sont pour la plupart en place, à des stades de développement et de stabilité fort différents.

Dans la plupart des cas, les postes entrée/sortie sont souvent si peu nombreux qu'on peut à peine parler de réseau. Dans d'autres cas, ils sont à peine québécois. Dans bien des cas, leur capacité de communication est si faible qu'il faut se contenter de parler de composantes éventuelles d'un réseau documentaire. A tout hasard, l'examen de quelques cas nous permettra davantage de voir les forces et les faiblesses, ainsi que le potentiel de développement. Nous profiterons d'ailleurs de toutes les occasions pour amener d'autres éléments de réflexion.

\section{L'Université du Québec (BADADUQ. S.I.G.I.R.D.)}

Le réseau de l'Université du Québec, par exemple, répond à plusieurs critères. II cumule plusieurs des qualités d'un réseau en vertu de sa capacité de communication qui rejoint un grand nombre de postes entrée/sortie. Il prend de plus en plus figure de serviteur d'une société; il demeure encore le plus québécois de nos réseaux, en ce sens qu'il appartient au Québec, est géré par lui et sert des Québécois qui d'ailleurs l'ont développé. II ne peut pas, du moins pas encore, être qualifié de réseau québécois, en ce sens qu'il ne peut pas couvrir l'ensemble ni la majeure partie du territoire, ni comme système indépendant, ni en potentiel de communication avec d'autres composantes-réseau.

II est intéressant de noter qu'il répond à une caractéristique additionnelle des réseaux, une caractéristique dont on a beaucoup parlé partout et qu'on cherche souvent à poser comme condition de développement et de permanence: par un jeu intéressant de participation, il jouit, tout en respectant une proportion fort intéressante d'autonomie locale, d'une unité de direction remarquable. II s'agit d'un modèle fort intéressant de bon équilibre entre la centralisation et la décentralisation.

II possède de plus une caractéristique dont on peut discuter longuement, laquelle a d'ailleurs causé un certain nombre de problèmes de conception, de développement et de perception, avec tout de même des résultats positifs: il est là, de façon avouée, pour servir d'abord ceux qui ont besoin de la documentation et non pas ceux qui en ont la garde, les utilisateurs plutôt que les intermédiaires. La bibliothèque, comme les réseaux, ne doit-elle pas être là comme un bon système, non pas en maître, mais en serviteur? Vous direz sans doute qu'il n'y a pas là de contradiction, que la bibliothèque bien servie par un réseau sera elle-même meilleur serviteur, et nous sommes d'accord. Le jeu des équilibres est tout de même légèrement différent et mérite peut-être qu'on s'y arrête: beaucoup d'autres, en effet, qui ont choisi de servir d'abord la bibliothèque et les bibliothécaires ont de la difficulté à s'en sortir pour passer à l'étape du système-réseau au service de l'utilisateur.

La finalité des services documentaires ne réside-t-elle pas au niveau des services aux usagers plutôt qu'au plan des services aux bibliothèques? Cette constatation, de toute façon, nous permet une réflexion supplémentaire: tout organisme, une fois créé, n'acquiert-il pas, incrusté dans son existence même, le réflexe de la "survivance"? Or, la survivance étant souvent une question de compétition et de pouvoir, même les réseaux peuvent en oublier leur finalité. Ce ne sont toutefois pas les composantes physiques du réseau qui peuvent ainsi réagir, mais bien plutôt ses composantes humaines. De là à dire que l'"agir en réseau" n'est pas naturel, est contre-nature, et cela dans la mesure où les composantes d'un réseau sont des individus (collectifs ou autres), il n'y a guère qu'un pas. II est plutôt naturel de tendre à l'autonomie complète et absolue, à la croissance continue; il est plutôt naturel et instinctif, pour y arriver, de bousculer les autres, de les faire disparaitre, de les absorber, de jouer la carte du pouvoir, de cacher son jeu ou de tricher. 
II faut donc croire que l'"agir en réseau" n'est pas du domaine de l'instinct, mais plutôt de l'ordre de la raison raisonnée. Cela est d'autant moins facile que, dans le champ des applications concrètes, il n'y a pas qu'une seule rationalité, ni une seule vérité. Cela est d'autant plus difficile que dans notre société dite évoluée, ni les multinationales, ni les P.M.E., ni les individus ne savent s'ils peuvent se permettre de limiter leur croissance, ou de laisser une place à l'autre. Les réseaux pourtant sont basés sur des principes de complémentarité et il faudra se rappeler que le jeu des équilibres est important: il suffira peut-être de raviver en sa mémoire cette grenouille qui voulut devenir aussi grosse que le boeuf. Quel gâchis!

De toute façon, y a-t-il avantage à mettre tous ses oeufs dans le même panier? $Y$ aurait-il avantage à risquer que s'effondre un jour toute la ville plutôt qu'un seul bâtiment, toute la machine parce qu'elle n'aura été constituée que d'une seule pièce?

C'est sans doute ce qui a permis à l'Université du Québec d'affirmer péremptoirement que son carré à elle se situait au plan des services à l'usager, qu'elle ne centralisait que l'essentiel, qu'elle dégageait pour chaque constituante une marge de manoeuvre appréciable, qu'elle ne retenait que les normes utiles et qu'elle comptait sur d'autres pour le reste. De cette originalité, elle doit être félicitée. L'avenir nous dira le reste, puisque, de toute façon, ceux qui demeurent sont toujours a posteriori déclarés d'évidence les plus aptes à survivre.

\section{RIBLIN}

RIBLIN, contrairement à S.I.G.I.R.D., est un réseau de services aux bibliothèques plutôt qu'aux usagers qu'il ne rejoint encore qu'indirectement. RIBLIN, en termes de réseau, regroupe une plus large audience, mais il n'a d'authenticité québécoise que par les bibliothèques qui, collectivement, achètent les services d'UTLAS. L'équilibre centralisation/décentralisation y est bien différent. La couverture documentaire $y$ est cependant plus large, et le degré d'autonomie globale plus considérable, bien que l'autonomie locale y soit bien plus restreinte. On a l'impression que la stabilité des composantes physiques y est plus grande, mais que la stabilité des composantes humaines laisse davantage à désirer: c'est sans doute une question d'inertie due en partie à la grosseur du système; c'est aussi une question de mauvais équilibre entre les pôles de centralisation et de décentralisation, puisque le degré d'autonomie laissé à chaque participant semble causer des insatisfactions.

Comme c'est une question d'équilibre, il n'est pas certain qu'on n'y arrivera pas: c'est là encore l'avenir qui le dira. Contentons-nous donc de constater deux choses. Dans le cas de RIBLIN il y a deux réseaux: celui qui regroupe les composantes physiques du système, et celui qui en regroupe les composantes humaines. C'est une sorte de mariage de raison et on ne sait pas si l'apparition d'un parti nouveau et attrayant ne ferait pas tout sauter. Deuxièmement, advenant un certain nombre de développements, dont un meilleur équilibre entre la centralisation et la décentralisation du traitement, ainsi que l'interconnexion, toutes les promesses sont permises.

\section{Centrale des bibliothèques}

Parmi les autres composantes d'un éventuel réseau québécois, nous ne mentionnerons la Centrale des bibliothèques que pour affirmer que, de notre point de vue, elle n'est pas un réseau. Elle fournit, au moyen d'un système encore très jeune, des services fort valables; mais elle ne parle pas encore beaucoup, et il n'y a pas que de sa faute, de la complémentarité si essentielle à un réseau. II faut espérer que les services offerts - puisqu'ils correspondent à des besoins actuels - continueront d'être offerts avec plus d'efficacité encore, tout en s'adaptant à l'évolution rapide des situations et en s'inscrivant dans ce nouveau contexte de complémentarité que l'interconnexion offrira. Là aussi l'équilibre centralisation/décentralisation aura besoin d'évoluer, à mesure que les bénéficiaires du système seront 
en mesure de devenir des participants plutôt que des clientèles, et, il faut bien le dire, des clientèles un peu piégées, comme d'ailleurs dans le cas de RIBLIN.

Cela nous amène à nous poser des questions sur le désir très largement exprimé de voir la "volonté politique" prendre l'initiative d'un modèle, pour seulement demander si c'est vraiment cela qu'on veut. C'est évidemment, là aussi, une question d'équilibre et de nuances, mais il faudra se rappeler que des participants enrégimentés ne sont habituellement pas longs à lever l'étendard de l'autonomie; que l'absence d'alternative est souvent considérée comme du totalitarisme et la négation pure et simple de l'initiative individuelle, de la créativité et de la liberté; que la faillite du seul réseau existant est fort plus désastreuse que la cassure d'une composante auxiliaire.

\section{Bibliothèques publiques}

Quant aux bibliothèques publiques, leur développement va bon train et leur avenir est plein de promesses: les attitudes-réseau sont en place. Le dénominateur commun que nous avons appelé leur capacité de communication est toutefois du domaine de l'avenir, si rapproché soit-il. Elles ont tout de même, comme l'Université du Québec, choisi de servir en premier leurs clientèles, même si, cette fois, c'est sans l'aide de l'informatique ou de la télématique. La base nous semble solide, et sans doute l'ère de l'interconnexion pourra-t-elle y prendre solidement racine.

\section{Informatech}

Nous garderons DOBIS pour la fin, puisqu'il y a lieu d'insérer ici mention d'un organisme qu'aucun des articles de ce numéro n'a exploré: Informatech. Nous considérons le rôle qu'il tente de jouer fort important: celui de rendre accessibles des informations documentaires québécoises qui ne seront pas autrement servies avec autant d'exhaustivité, ni de façon aussi systématique; si de plus on considère son rôle d'intermédiaire quant à la mise en disponibilité à l'étranger des banques québécoises, comme aussi son rôle d'aiguilleur quant à la disponibilité en langue française des banques documentaires étrangères, nous avons affaire à un candidat tout à fait valable comme composante essentielle d'un réseau documentaire québécois.

\section{Bibliothèque nationale du Québec}

Nous devons également mentionner la Bibliothèque nationale du Québec, au moins pour dire qu'il ne s'agit pas d'un réseau, mais d'un service au réseau: un service qui utilise l'informatique pour se réaliser, mais qui n'est encore actualisé au plan de la communication, c'est-à-dire comme composante du réseau, que par divers moyens traditionnels, sauf le cas du Fichier MARC québécois par le biais d'UTLAS, ainsi que de RADAR par Informatech. La Bibliothèque nationale du Québec devra toutefois prendre place comme composante essentielle d'un réseau documentaire québécois, sauf si l'évolution nous faisait choisir, en lieu et place, un réseau documentaire canadien.

II est bien sûr que, pour y arriver, la Bibliothèque nationale du Québec devra se doter des accessoires qui permettront l'interconnexion et améliorer grandement la qualité de son potentiel de communication surtout en termes de délai et de complémentarité. Cette partie du réseau dépend nettement de la volonté politique du gouvernement et de la société québécoise, contrairement à plusieurs autres composantes du réseau dont nous avons l'impression qu'elles sont une question de concertation et de volonté de se coordonner plutôt que de simple coordination.

\section{Et les autres...}

Avant de passer à DOBIS, nous aimerions mentionner aussi qu'il y a d'autres composantes nécessaires au réseau, dont les collèges, les écoles, les compagnies et les diverses sociétés. II n'est pas nécessaire, loin de là, que toutes ces composantes 
se rallient à un seul modèle, mais il sera nécessaire qu'elles se regroupent sur des bases allant du territoire à l'expertise, en passant par les spécialisations, le traitement de la documentation et son accessibilité: pour tout résumer, sur des bases de similitudes, puis, sur la base de la complémentarité.

\section{DOBIS}

DOBIS nous apparaît comme une composante-réseau nécessaire, peut-être la plus intéressante. Comme I'Université du Québec, la Bibliothèque nationale du Canada s'est inscrite dans un modèle global où elle est prête à jouer son rôle de Bibliothèque nationale favorisant la régionalisation, la normalisation, l'interconnexion et l'accessibilité. Nous fondons d'ailleurs beaucoup d'espoir en l'interconnexion du réseau Bibliothèque nationale du Canada et du réseau Université du Québec. La seule ombre au tableau ne relève pas de la dynamique des réseaux, mais de la politique. Comme le Québec, ou inversement le Canada, a de la difficulté à se définir par rapport à l'autre, de même la Bibliothèque nationale du Canada et la Bibliothèque nationale du Québec n'ont pas réussi à s'accepter ou à se définir en termes de complémentarité. Sans se demander si ce sera une question de temps ou une question de survie, nous allons tout de même tenter d'imaginer ce que pourrait être le réseau documentaire québécois, maillon du réseau documentaire mondial.

Disons tout de même en passant que le bilinguisme du MARC canadien nous est toujours apparu comme une erreur. La documentation est polyglotte, il est vrai, mais le document et l'usager sont la plupart du temps unilingues, de sorte que, en réseau, le multilinguisme devrait être traité au plan des fichiers d'autorité et permettre à celui qui utilise le document ou à celui qui utilise le système-réseau de travailler dans la langue de son choix. Tout le reste est politique. Il faut cependant admettre que DOBIS assume déjà de la bonne façon, au niveau du système plutôt qu'au niveau des documents, ce support linguistique.

Supposons un instant que le Québec puisse se considérer de droit et de fait comme un territoire défini dans le découpage du monde, quant aux préoccupations des principes du Contrôle bibliographique universel et de l'Accès universel des publications. Le Québec pourrait alors gérer une réplique du système DOBIS, laquelle serait interconnectée au système DOBIS du gouvernement fédéral, I'un et l'autre DOBIS supportant une partie complémentaire des différents MARC nationaux, et $y$ insérant au jour le jour son propre MARC. Le DOBIS QUEBECOIS constituerait une alternative valable pour un certain nombre de bibliothèques. L'Université du Québec garderait son système (et pourrait d'ailleurs l'exporter), et serait, par interconnexion, client et fournisseur du DOBIS QUEBECOIS et du DOBIS CANADIEN tant au niveau des données bibliographiques qu'au plan de l'accessibilité au document. La Centrale des bibliothèques pourrait alors jouir des mêmes avantages et en profiter pour donner à son système une expansion-réseau. D'autres composantes/réseaux relativement simples ou complexes pourraient voir le jour et non seulement joindre le réseau québécois, mais contribuer à sa formation. Les membres de RIBLIN auraient enfin le choix.

\section{CONCLUSION}

Pourquoi cela n'arrive-t-il pas? Est-ce une question technique ou financière? N'est-ce pas plutôt une question à deux volets: politique d'une part et de coordination d'autre part? II reste à faire deux choix vraiment fondamentaux: un choix politique bien sûr; mais aussi un choix qui consiste à définir la coordination, ou l'équilibre entre se coordonner et être coordonné. C'est peut-être après tout une simple question de leadership que seule l'émergence d'un leader pourra régler. Autrement, comme c'est I'habitude, c'est la raison du plus fort qui sera la meilleure. Seul celui qui survivra pourra nous dire lequel méritait de survivre, puisque c'est toujours celui qui gagne qui était le meilleur. II n'y a pourtant pas lieu d'être aussi pessimiste, car la complémentarité demeure nécessaire, de plus en plus nécessaire, et c'est elle qui, la raison aidant, gagnera la partie. 


\title{
A library and information network for Quebec
}

\author{
Marcel Fontaine* \\ Bibliothèque nationale du Québec \\ Montréal
}

A reading of the articles in this issue offers an up-to-date information on many aspects of the library and information network in Quebec, its evolution, its main elements, its aims, the state of its growth, and its hopes for the future. These articles will bring adequate answers to some questions, and our main hope is that they will raise many more on other facets of the subject.

\section{Some commonplace thoughts on networks}

Networks can be compared to systems and societies. They can be small or large, simple or complex; they can, inasmuch as they exist, be active or latent. Let us look, for instance, at the telephone: this comparison is most adequate as the telephone is a network involving many systems; furthermore, it is a means of communication. No one can deny that communication is the common denominator in societies, systems, and networks, all of which are never better than the quality of their communications.

By proceeding in this allegorical manner, we will spare ourselves the problems of terminology and definitions. To be fully understood, these have to be explained at length and they deserve more than a short and marginal treatment. As we are indulging in broad thinking, we do not feel the need to be so thorough: we will use comparisons and explanations in lieu of definitions; a multiple choice of meanings for the words not clearly defined will open the door to various interpretations, and will provoke, we hope, more systematic and learned thoughts.

When a certain number of elements are coordinated in a certain manner, there is a potentiality of interaction (i.e. of communication): they form a system. When certain other conditions are present, this potentiality becomes a real interaction: what was latent becomes active. And when the system is used by man in a conscious way, it becomes a communication tool.

If the telephone, for instance, were limited to two in/out devices, it would be a very small system indeed: even multiplied by a million, it still would only represent a million small systems. It is thus in the complexity resulting from the choice and the quality of its parts that a system can be improved; by adding more in/out devices, i.e. by multiplying its outlets, it grows and can be called a network. By the same token, only when it is in use that it is active and communication is then established; when it is always ready to function, it is effective; finally, and in a very odd way, to the same extent it can remain inactive even when ready to be used, it can also evolve from the role of master to that of servant.

\section{A library and information network in Quebec}

Now that we have laid down these elements of comparison, let us try and understand: what of the library and information network in Quebec? To start with, does it exist? Without any hesitation, we must answer that there is no library and information network yet in Quebec. There is something, better yet, there are many things. Most of the future components are in place, in various stages of development and stability.

In most cases, the in/out devices are so few in number that one cannot speak of a network. In other instances, they are not Quebec-born and show little affinity with the needs in Quebec. In many cases, their capacity to handle communications is so low that we can only mention them as eventual components of an information network. A survey of a few types will allow a better understanding of their strong and weak points, as well as of their growth potential. In any case, we will seize every opportunity to bring more food to our thought.

* The author is Assistant to the Director of the Bibliothèque nationale du Québec 


\section{The Université du Québec (BADADUQ, S.I.G.I.R.D.)}

The network of the Université du Québec, for instance, is many sided. It holds many of the properties inherent to a network because of its communicating capacity which connects a great number of in/out devices. It increasingly reveals itself as a servant of society; it is the most truly home-born of all our networks, for it belongs to the Province of Quebec, is managed by people in Quebec and it serves those who have created it. It cannot as yet be called a network for the whole of Quebec, as it cannot cover all or the greater part of the territory, neither as an independant system, nor as a system with potential means of communication with other network components.

An interesting fact is that it presents an additional trait of a network, a trait which is much discussed and which is often laid down as a condition for development and stability: through an interesting interactive play, it enjoys, while respectful of a strong local autonomy, a remarkable management control. It is a noteworthy example of a good balance of power between centralization and decentralization.

It also presents a feature which can be argued at length and which has been the source of many problems in conception, development and perception, although with positive results: its avowed purpose is to first serve those in need rather than those in charge of information, the users before the agents. To be a worthwhile system, shouldn't the library, as any other network, be a servant rather than a master? You might undoubtedly answer that there is no contradiction in that fact, that a library well supported by a network will itself be a good servant. We do agree. The forces at work are nevertheless slightly different and deserve a moment of our attention: in fact, many others who had elected to serve libraries and librarians first have found difficult the transition to a network system aimed at the user.

Is not service to the users rather than to the librarians the ultimate goal of library and information services? In any case, this statement offers another thought: does not any system, once created, acquire, ingrained in its very being, the reflex of survival? As survival often implies competition and power, even the networks might then forget their objectives. However, this reaction does not grow from the material but from the human components of the system. It follows that it might be easy to infer that a "network action" is not natural, is against nature, and this to the extent that the components of a network are individuals (in a group or otherwise). It is more natural to strive for total and absolute autonomy, for a continuous growth; in order to achieve that goal, it is more natural and instinctive to hustle the others, to elbow them out, to absorb them, to play the power game, to be underhanded or to cheat.

One must then believe that a "network action" is not instinctive, but is a result of the reasoning powers. This is the more difficult in our so-called advanced society, as neither the multinational corporations, nor the small businesses, nor the individuals know if they can afford to limit their growth or make place for others. And yet, networks are based on principles of complementarity, and we must remember that the balance of power is important: on should not forget the story of the frog that tried to be as big as an ox. What a mess!

Is there any advantage to be gained in putting all one's eggs into one basket? Would there not be the risk that the whole city crumble instead of a single building, that the whole system collapse because it was built of one piece?

This might be the reason why the Université du Québec has been able to state positively that its territory consisted in the service to the users, that it was centralizing only the essential services, that an appreciable work latitude was awarded to each of its constituents, that it was holding control of only the useful standards, and that it was relying on others for the rest. It must be congratulated 
for this innovation. The future will bear witness, since, in any way, those who last are considered a posteriori as the most apt to survive.

\section{RIBLIN}

RIBLIN, as compared to S.I.G.I.R.D., is a network aimed at serving libraries rather than users whose needs are indirectly met. RIBLIN as a network groups a larger set, but its authenticity as a Quebec network holds only through the libraries that collectively buy the services of UTLAS.. The balance between centralization and decentralization is quite different. The volume of information treated is much larger. and the degree of overall autonomy is much greater, though the local autonomy may be more restricted. One feels that there is more stability in the material components, but that the human continuity is not quite as satisfactory: it stems without doubt from a problem of passiveness, due in part to the large size of the system; there is also a problem of balance between the centralization and the decentralization poles, since the degree of autonomy left to each constituent seems to bring dissatisfaction.

As it is a problem of balance, let it not be said that it cannot be achieved: there also, the future will bear witness. Let us merely point out two things. In the case of RIBLIN, there are two networks: one is constituted of all the material components of the system; the other is made of all its human elements. It is a kind of marriage of convenience, and one can never be sure whether the appearance of a more attractive prospect would not blow the whole deal. Secondly, with the advent of a number of developments, of which a better balance between the centralization and decentralization of the technical processing, and the coming of interconnection, all hopes are permitted.

\section{La Centrale des bibliothèques}

Among other constituents of an eventual Quebec network, we will mention La Centrale des bibliothèques only to state that, from our point of view, it is not a network. It provides very good services through a still young system; but there is no talk yet of complementarity, such an essential part of a network, even though the blame cannot be all laid to its door. One must hope that the services available and they meet a real need - will go on being offered with even more effectiveness, while meeting the rapid evolution of circumstances, and getting more involved in this new concept of complementarity offered by interconnection. There too the balance between centralization and decentralization will have to evolve, as the users of the system will become more apt at being participants rather than clients, and, it must be said, clients who have little other choice as in the case also of RIBLIN.

This brings us to wonder whether the widely expressed wish to see the state control the initiative of a model, is really what we really want. There is obviously a question of balance and degrees, but we must bear in mind that enrolled members do not usually take long to raise the flag of autonomy; that the lack of an alternative, is often considered as a dictatorship and a downright denial of individual initiative, creativity and liberty; that the failure of the only network in existence is far more disastrous than that of an auxiliary component.

\section{The public libraries}

The growth of public libraries is off a good start and their future holds many a promise: the network way of thinking is there. The common denominator, which we have called their capability to communicate, is however still a thing of the future, be it as near as can be. Nevertheless, like the Université du Québec, they have chosen to meet their users' needs first, even if here it is without the help of computers or telecommunications. The foundation seems sound, and we have no doubt that the era of interconnection will solidly take root in it. 


\section{Informatech}

We will talk of DOBIS later on, for we would like to mention here a system not reported in this issue: Informatech. We deem its role important: to make available information data about Quebec which will not be treated in such a thorough or systematic way. Furthermore, in view of its role of go-between in the offering of Quebec data banks to other countries, as well as that of researcher as to the availability of foreign data bases in French, it is a worthwhile candidate for an essential component of a Quebec information network.

\section{Bibliothèque nationale du Québec}

We must also take into account the Bibliothèque nationale du Québec, at least to state that it is not a network, but rather a service to the network: a computerized service, but still using various traditional means of communication, that is to say from the point of view of a network component, except in the case of the Quebec MARC data base through UTLAS, , and of RADAR through Informatech. The Bibliothèque nationale du Québec will have to eventually take its place as an essential component of a Quebec information network, unless events would lead us to opt for a Canadian network.

To achieve this goal, it is clear that the Bibliothèque nationale du Québec will have to equip itself with the terminals necessary for interconnection, and it will also have to greatly improve the quality of its communication potential, mostly as to delays and complementarity. This part of the network is directly dependent of the political will of the government and of the people of Quebec, as compared to other components where we have the feeling that they depend on a question of concertation and of a will to work jointly rather than on mere coordination.

\section{And the others...}

Before we proceed to DOBIS, we would like to mention other essential components of the network, such as colleges, schools, firms and various associations. Far from having to adopt a unique model, all these components will nevertheless have to meet on different levels, from territories to expertise, as well as specializations, technical processing and availability of information: in a word, on the basis of their similarities, and then on a basis of complementarity.

\section{DOBIS}

DOBIS seems to us an essential network component, maybe the most interesting one. Much like the Université du Québec, the National Library of Canada has opted for an inclusive model enabling it to play its role as a national library, promoting regionalization, standardization, interconnection and accessibility. There is much hope in the results of an interconnection of the National Library of Canada and the Université du Québec networks. The only shade of gloom in this bright picture cannot be attributed to network dynamics, but to politics. As Quebec, or inversely Canada, has difficulty in defining itself in relation to the other, the National Library of Canada and the Bibliothèque nationale du Québec have not yet managed to accept of define their complementarity. Without asking ourselves whether it will be a matter of time or of survival, let us try to imagine what could be called a Quebec information network, a link in a worldwide information network.

Let us just say here that the bilingualism of the Canadian MARC seems to us a mistake. The information is polyglot, it is true, but most of the documents and the readers are unilingual, so that multilingualism in a network should exist at the authority files level and allow the user to work in the language of his choice. And everything else is politics. We must admit, however, that DOBIS already assumes that linguistic support at the system level if not at the documentary level. 
Let us imagine for a moment that Quebec were entitled as an actual nation of the world, from the point of view of the principles laid down by the Universal Bibliographic Control and the Universal Availability of Publications (UAP). Quebec could then manage a replica of the DOBIS system, connected to the federal government's DOBIS system, both DOBIS sharing in the processing of the MARC from other countries, and with the possibility for each to enrich regularly its own MARC. The Quebec DOBIS would offer a valid alternative to many libraries. The Université du Québec would maintain its own system - and could even offer it to other countries - and would become, through interconnection, client and supplier of both the Quebec DOBIS and the Canadian DOBIS, from a bibliographic standpoint as well as where accessibility is concerned. La Centrale des bibliothèques could avail itself of the same benefits and take the opportunity to grow into a network. Other networks, whether simple or complex, might see the day, and not only be connected to the Quebec network, but also contribute to its growth. The members of RIBLIN would then be presented with a choice.

\section{Conclusion}

Why does it not happen? Is it a matter of technology or of financial means? Is it not rather a two-sided problem: politics on one side, and coordination on the other? Two basic choices remain to be made: a political one, of course; but also a choice tending to define coordination, or the balance between coordinating oneself or being coordinated. It might merely hinge on a problem of leadership, in which case only the rise of a leader could solve it. Otherwise, as usual, might will be right. However, pessimism is uncalled for, because complementarity is essential and it will prevail with the help of good sense.

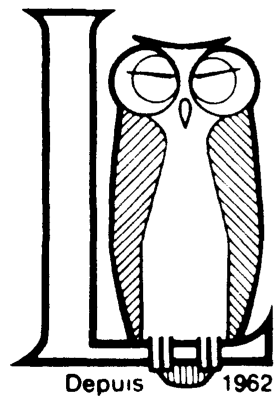

\section{R.M. LEDUC \& CIE BIBLIOTHEQUES}

\section{MAINTENANT: SERVICE DE RÉPARATION ET RELIURE DE LIVRES ET PERIODIQUES.}

PROTECTEURS DE LIVRES EN FILM POLYESTER • PELLICULES AUTO-ADHÉSIVES — RUBAN DE LECTO-CONTACIOU PELLIMAT • DÉVIDOIRS • TRICOL • PROTÉGE-FICHES VERTICAL, HORIZONTAL OU SURELEVÉ • FICHESGUIDE - PROTEGE-PÉRIODIQUES - POCHETTES DE VOLUME - ÉTIQUETTES COLLANTES LECTO-DURO • ÉTIQUETTES AUTO-ADHÉSIVES - COLLE PLAXANOL • PERFORATEURS - MATÉRIEL D'EXPÉDITION - RUBANS AUTO-ADHÉSIFS - DOSSIERS SUSPENDUS • CHEMISES - ENVELOPPES PAPIER KRAFT REMBOURRE.

C.P. 1379, Marieville, Qué. JOL 1JO (514) 658-0661 